\title{
A Multidimensional Welfare Status of Leprosy Patients Living in a Suburban Area
}

Yunia Irawati

Department of Ophthalmology, Faculty of Medicine, Universitas Indonesia, dr. Cipto Mangunkusumo Hospital, Jakarta, Indonesia, yunia_irawati@yahoo.com

Sri Linuwih SW Menaldi

Department of Dermatology and Venereology Faculty of Medicine Universitas Indonesia, dr. Cipto Mangunkusumo Hospital Jakarta, Indonesia, susetyo_mr@yahoo.com

See next page for additional authors

Follow this and additional works at: https://scholarhub.ui.ac.id/ajce

Part of the Arts and Humanities Commons, Business Commons, Life Sciences Commons, Medicine and Health Sciences Commons, Physical Sciences and Mathematics Commons, and the Social and Behavioral Sciences Commons

\section{Recommended Citation}

Irawati, Yunia; Menaldi, Sri Linuwih SW; Harini, Melinda; Wahyuni, Luh Karunia; Alwin, Wanarani; Dwiranti, Astari; Menaldi, Adhityawarman; Luzanil, Sonny Tirta; Matsurah, Qaishum; ., Dadun; Kurniawan, Rico; Ruwaida, Ida; Wicaksono, Gunawan; Sahid, Muhammad Hidayat; Rahmayanti, Febrina; Priscilia, Florentina; Fitriana, Anis; Rahayu, Tri; Susiyanti, Made; Andayani, Gitalisa; Bani, Anna Puspitasari; Daniel, Hisar; and Lestari, Yeni Dwi (2021). A Multidimensional Welfare Status of Leprosy Patients Living in a Suburban Area. ASEAN Journal of Community Engagement, 5(1), 71-104.

Available at: https://doi.org/10.7454/ajce.v5i1.1088

Creative Commons License

(c) (i) ()

This work is licensed under a Creative Commons Attribution-Share Alike 4.0 License.

This Research Article is brought to you for free and open access by the Universitas Indonesia at ASEAN Journal of Community Engagement. It has been accepted for inclusion in ASEAN Journal of Community Engagement. 


\title{
A Multidimensional Welfare Status of Leprosy Patients Living in a Suburban Area
}

\author{
Yunia Irawati $^{1^{*}}$, Sri Linuwih SW Menaldi ${ }^{2}$, Melinda Harini ${ }^{3,4}$, Luh \\ Karunia Wahyuni ${ }^{3,4}$, Wanarani Alwin ${ }^{3,4}$, Astari Dwiranti ${ }^{5}$, Adhityawarman \\ Menaldi $^{6}$, Sonny Tirta Luzanil ${ }^{6}$, Qaishum Matsurah ${ }^{6}$, Dadun ${ }^{7}$, Rico \\ Kurniawan $^{8}$, Ida Ruwaida9, Gunawan Wicaksono ${ }^{10}$, Muhammad Hidayat \\ Sahid $^{10}$, Febrina Rahmayanti ${ }^{11}$, Florentina Priscilia ${ }^{12}$, Anis Fitriana ${ }^{12}$, Tri \\ Rahayu $^{13}$, Made Susiyanti ${ }^{13}$, Gitalisa Andayani ${ }^{13}$, Anna Puspitasari Bani ${ }^{13}$, \\ Hisar Daniel $^{13}$, Yeni Dwi Lestari ${ }^{13}$ \\ ${ }^{1}$ Department of Ophthalmology, Faculty of Medicine, Universitas Indonesia, dr. Cipto Mangunkusumo \\ Hospital, Jakarta, Indonesia \\ ${ }^{2}$ Department of Dermatology and Venereology Faculty of Medicine Universitas Indonesia, dr. Cipto \\ Mangunkusumo Hospital, Jakarta, Indonesia \\ ${ }^{3}$ Study Programme of Physical Medicine and Rehabilitation, Faculty of Medicine, Universitas Indonesia, \\ Jakarta, Indonesia \\ ${ }^{4}$ Department of Rehabilitation Medicine, dr. Cipto Mangunkusumo Hospital, Jakarta, Indonesia \\ ${ }^{5}$ Department of Biology, Faculty of Mathematics and Natural Sciences, Universitas Indonesia, Depok, Indonesia \\ ${ }^{6}$ Faculty of Psychology, Universitas Indonesia, Depok, Indonesia \\ ${ }^{7}$ Center for Health Research Universitas Indonesia, Faculty of Public Health, Universitas Indonesia, Depok, \\ Indonesia \\ ${ }^{8}$ Department Biostatistics and Population Studies, Faculty of Public Health, Universitas Indonesia, Depok, \\ Indonesia \\ ${ }^{9}$ Faculty of Social and Political Sciences, Universitas Indonesia, Depok, Indonesia \\ ${ }^{10}$ Occupational Therapy Department, Vocational Educational Program, Universitas Indonesia, Depok, \\ Indonesia \\ ${ }^{11}$ Oral Medicine Department, Faculty of Dentistry, Universitas Indonesia, Jakarta, Indonesia \\ ${ }^{12}$ Research Assistant, Department of Ophthalmology, dr. Cipto Mangunkusumo Hospital, Jakarta, Indonesia \\ ${ }^{13}$ Department of Ophthalmology, Faculty of Medicine, Universitas Indonesia, dr. Cipto Mangunkusumo \\ Hospital, Jakarta, Indonesia \\ *Correspondence email: yunia_irawati@yahoo.com \\ Received: May $27^{\text {th }}, 2020$, Accepted: March $24^{\text {th }}, 2021$
}

Abstract Leprosy has a high incidence of physical complications that will impact directly the physiological, economic, and social status of patients. Indonesia has a high burden of the disease, and several leprosy settlements are still spread in the country. Neglasari Village, Sitanala, Tangerang serves as one of the places of residence of people who have had leprosy. A health service initiative known as 
Identifikasi Tanda-Tanda Mata, Ekstremitas, dan Kulit pada Kusta (KATAMATAKU) was launched as a collaboration of health services among multi-departments (ophthalmology, dermatovenereology, and medical rehabilitation). Sitanala has a relatively high incidence of people who have had leprosy with disabilities of the hand, foot, and eye. As a continuation of this health service and combined with the efforts to improve the welfare of leprosy patients, in November 2019, a multidisciplinary program titled KATAMATAKU Universitas Indonesia, was conducted. This program aimed to determine the demographic data regarding the health, psychological, social, and economic status of the leprosy population at Sitanala The project consisted of a collaborative anti-stigma program by the Faculty of Psychology, Public Health, Social and Political Sciences, Cultural Sciences, Administrative Sciences, and Vocational Educational Program; thematic health program, which supports the improvement of physical abilities and empowerment of former leprosy patients, by the Faculty of Medicine, Dentistry, Nursing, and Pharmacy; thematic economics program, which aims to increase the economic capacity of the leprosy community, by the Faculty of Economics and Business, Mathematics and Natural Sciences, and Engineering. This program enabled the construction of a multidimensional management model, in which every aspect plays important roles to improve the patients' quality of life.

Keywords: multidimensional; leprosy; health service; anti-stigma; economic capacity; community; welfare.

\section{Introduction}

Leprosy is a chronic and progressive infectious disease caused by the infection with Mycobacterium leprae. The disease is still found in developing countries given the limitations of the provided adequate services in the fields of health, education, and socioeconomic welfare in society. Southeast Asia has the highest number of new leprosy cases, and Indonesia is the third highest country in the world with leprosy, after India and Brazil (Hogeweg, 2010; WHO, 2018). The leprosy prevalence rate in Indonesia was 0.72 per 10,000 populations in 2018. The number of leprosy cases was 19,033 cases, which is the largest value of prevalence per 10,000 populations (Kemenkes, 2017). The number of new leprosy cases found was 14,397 cases. Leprosy patients usually live together and called their area a settlement, with the stigma from general communities restricting them to live among a common crowd (Kemenkes, 2018). Sitanala is one of such settlements and is located within the area of Sitanala Hospital in Tangerang, Banten, which is the border of rural and urban areas near Jakarta, the capital city of Indonesia.

Community engagement refers to the process of working collaboratively with and through groups of people affiliated by geographic proximity, special interest, or similar situation to address issues affecting their wellbeing (CDCP, 1997). This activity can be held by organized groups, institutions, or individuals involved in health promotion, policy making, and research. 
The collaboration is interdisciplinary, including the fields of healthcare, psychology, sociology, economic, social work, political science, and other discipline that contribute to community development. To carry out a successful collaboration with community, the provider needs to understand the point of view of the "insiders" and observe the community culture and behavior that shaped the community's belief about their health condition. An essential point of community engagement is helping the community to discover the root cause of population's problems, search for solutions, develop ideas, contribute to decision making, share responsibility, and build the community (CTSA, 2011).

The high incidence data of leprosy in Indonesia encouraged Identifikasi Tanda-Tanda Mata, Ekstremitas, dan Kulit pada Kusta Universitas Indonesia (KATAMATAKU UI) to conduct a health service program for leprosy patients. Leprosy is not only related to health problems but also affects other aspects of life, such as economy, psychology, social, culture, and others. In this program, KATAMATAKU UI combined forces from multiple faculties and departments to overcome the several aspect problems of leprosy patients. KATAMATAKU UI was sub-clustered into three thematic teams. The anti-stigma thematic team consists of the Faculty of Psychology, the Faculty of Public Health, the Faculty of Social and Political Sciences, the Faculty of Cultural Sciences, the Faculty of Administrative Sciences, and the Vocational Educational Program, and it aims to increase the social capacity for the leprosy community.

The health thematic team consists of the Faculty of Medicine, the Faculty of Dentistry, the Faculty of Nursing, and the Faculty of Pharmacy, and it supports the improvement of physical abilities and the empowerment of leprosy sufferers. The thematic economics team consists of the Faculty of Economics and Business, the Faculty of Mathematics and Natural Sciences, and the Faculty of Engineering, and it aims to increase the economic capacity of the leprosy community. The impact of the application of knowledge, science, and technology from each discipline is expected to be felt by the community and to improve their standard of living. In addition, the community can develop the knowledge they have gained with interesting innovations.

Currently, several multidimensional programs have been carried out to improve the standard of living and quality of life of the leprosy community. The program of KATAMATAKU UI serves as a model of multidimensional management of leprosy patients, and it is the first multidimensional program for the leprosy population in Indonesia. The hypothesis of this descriptive study includes the multi-aspect life problems of leprosy patients, including health, economy, psychology, education, and others. Hence, 
KATAMATAKU UI started this multidimensional program to overcome the multi-aspect problems of leprosy patients with the Sitanala settlement as the model for other leprosy settlements nationally or globally.

This study aimed to determine the demographic data regarding the health, psychological, social, and economic status of the leprosy population at Sitanala. By obtaining these data, appropriate studies and interventions can be carried out to reduce the level of disability, prevent further disability, eradicate leprosy, and end stigma. Furthermore, the social and economic welfare of the citizens can be improved. This research is limited to several samples and data analysis. This research intended to perform the holistic management of each aspect, which will altogether overcome the problems in leprosy society. On a large scale, this work will optimize the quality of life of leprosy patients and community empowerment.

\section{Methods}

The "KATAMATAKU UI" multidisciplinary service program was conducted by a team consisting of several experts and held at the leprosy settlement village in Tangerang City in November 2019. All the members coordinated and collaborated as a multidisciplinary team to create a holistic solution to achieve public welfare.

The program started with the preparation by each expert, followed by the coordination of the whole master plan with the local government and hospital near the Sitanala settlement. Routine meetings and approaches to the residents were carried out, starting from the local government. The multidisciplinary team met with the board of Sitanala Hospital to discuss and match the programs' proposal to community needs (Figure 1). The anti-stigma thematic team started the program one and half weeks before the collaboration program by collecting the database of every resident in RT 01 RW 13 Sitanala settlement village. The databases contain personal and demographical information from the village officers, followed by the door-to-door survey to match the database with real data. The data consisted of personal, health, and demographical information. A baseline survey was conducted to assess the latest condition in the study site before the intervention. This survey aimed to explore the various views of the population toward the knowledge, attitudes, and practice on leprosy and its impacts, such as on the quality of life and stigmatization. 

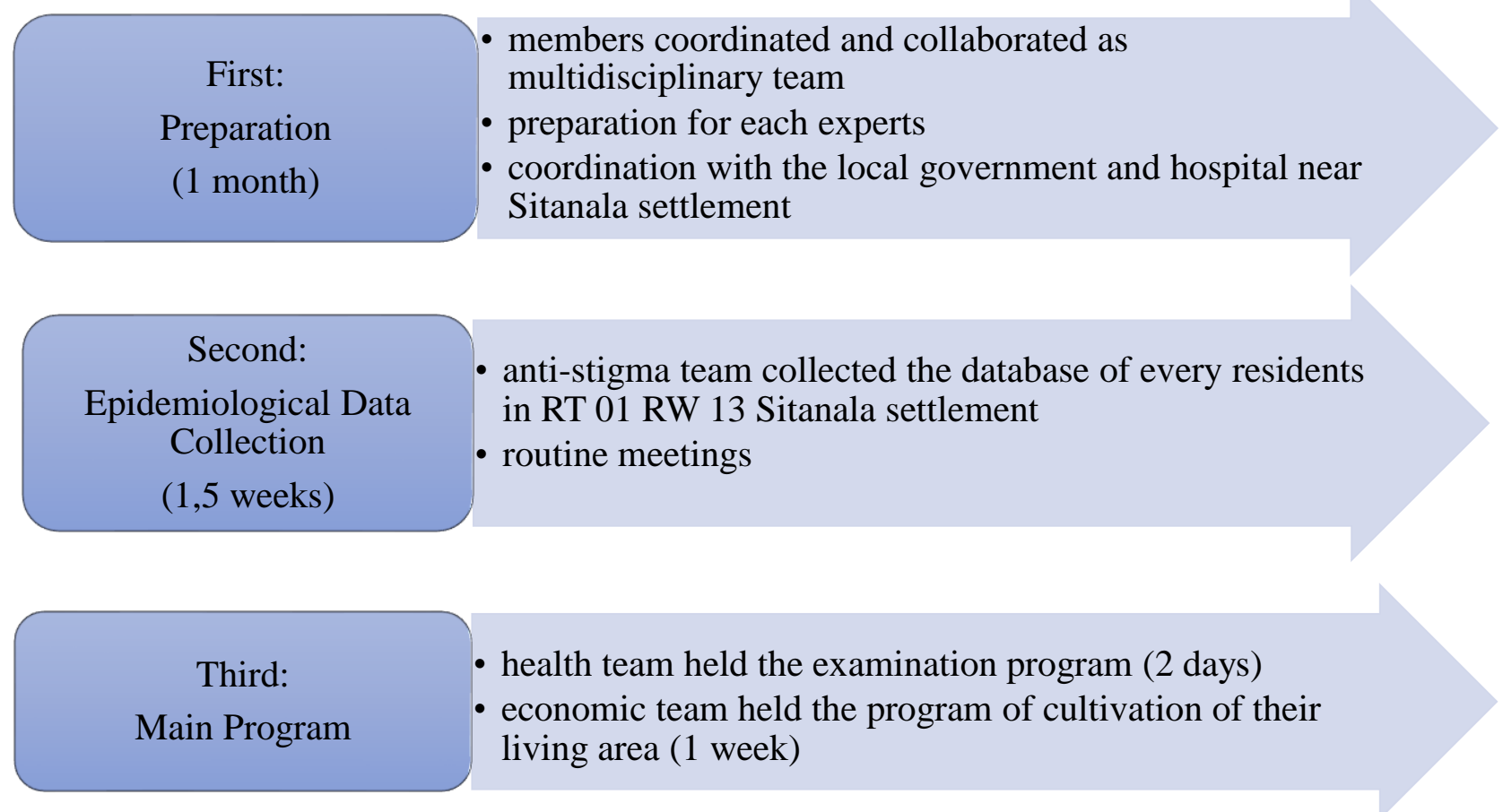

Figure 1. Flowchart of the Program for Sitanala Resident

Furthermore, the health thematic team focused on leprosy patients, especially those with impairment of the eye, skin, the extremities, oral and dental, and psychological health. The team targeted residents based on the data collected by the anti-stigma thematic team. The data were developed as a full database of the whole health status of the community. Then, the patients were treated by the multidisciplinary team to achieve their optimal welfare status by increasing their ability to perform their social, economic, and cultural roles in the community. The examination program was held at Sitanala Hospital Sports Hall and the settlement area, which is around $100 \mathrm{~m}$ from the sports hall. The participants were all residents of RT $01 \mathrm{RW}$ 13 Sitanala settlement village. A total of 304 subjects were included. Upon arrival, the participants must approach the registration table to match their data with the database, and they were given different forms based on their leprosy status.

A red form was given to leprosy and ex leprosy patients; a yellow form was given to the family member who lived at the same house with the leprosy and ex leprosy patients, and a green form was given to family members who have no leprosy patients living in the same house. The participants brought their forms to the first session, which was an interview regarding their real personal data and involved the acquisition of verbal and written informed 
consent. If the participants agreed, the committee continued the interview about their health history and disease and their subjective opinion about their quality of life in the form of a questionnaire. Afterward, a series of examinations was carried out.

Ophthalmology examinations were performed to detect eye abnormalities in residents of the leprosy settlement (leprosy and non-leprosy). A total of 18 ophthalmologists, 13 general practitioners, and 4 refractionists were involved in this examination. The eye examinations included uncorrected and best-corrected visual acuity, intraocular pressure measurement, and anterior segment examination. Posterior segment examination was mandated if visual acuity was not concordant with the anterior segment examination, using indirect funduscopy with 90D lenses and/or binocular indirect ophthalmoscope. Ocular abnormalities were documented in the eye examination section of the form. The dermatovenereology examination started with the investigation of rifampicin administration as chemoprophylaxis for household contacts, the Dermatology Life Quality Index, and examination.

The questionnaire was administered and followed up with an in-depth interview (Romero, 2012). The study about the quality of life of leprosy patients is still ongoing; in collaboration with the Faculty of Pharmacy, patients who do not live in the same residential area and administrating medical prevention were compared with those who live in the same residential area as a leprosy patient (Girdhar, 2016). Simultaneously, an examination of nail abnormalities was conducted, along with clinical and dermoscopic observations followed by a physical examination of the upper and lower extremities, including the range of motion and manual muscle test (MMT) by an occupational therapist (Kaur et al., 2003). The products and activities of daily living and leisure were identified. Each muscle group was tested bilaterally during MMT. The occupational therapists commonly used a goniometer, which is an instrument that measures the angle of a joint, to measure the range of motion. The deformity and functional level of the joint were documented after conducting these assessments. The oral medicine team from the Faculty of Dentistry examined the status of oral and dental health as an integrated part of the clinical examination of patients with leprosy in this health service. Furthermore, the dentist team provided information and educated people with leprosy. The appropriate treatment of dental infections can reduce recurrence in leprosy patients (Pallagatti et.al, 2012).

Using the rehabilitation principle of participation limitation, the medical rehabilitation team designed art activities for leprosy villagers in Sitanala. Art activity was selected because it is one of strategies for yielding new insights into and acceptance toward leprosy patients (Hasnain, 2020; Reis, 2017). Social acceptance is also related to the stigma attached to 
leprosy survivors and their children. Through focus group discussions, the social and cultural team attempted to identify the experiences and strategies for facing stigma among young peoples.

To achieve optimal results, the Department of Psychology developed an assessment of intervention and examination by Hopkins Symptoms Check List-25 (HSCL-25), which is a measurement tool that can screen a person's psychological distress levels (Hutahaean \& Sumampouw, 2018; Hutapea \& Mashoedi, 2019; Turnip \& Hauff, 2007). The focus of the review was on the team's findings regarding the level of psychological distress of Sitanala villagers as baseline data to determine interventions which would then be arranged as a further step. In the next step, our team conducted a lesson to remove the social stigma to improve the quality of life of people with leprosy.

The community welfare was achieved by increasing the economic and social life of the leprosy community. This goal was manifested by a continuous program for cultivation in the area, including hydroponics and organic waste management. These programs were selected to support people with leprosy and their relatives with practical and valuable activities. Twenty individuals (10 males and 10 females) with leprosy in Sitanala joined the program. The program was divided into the 1) introduction of hydroponic and organic composting through interactive presentation and examples; 2) hands-on hydroponic and waste processing; 3) program evaluation.

The nutrient film technique (NFT) in hydroponics was applied in this program, along with the installation of solar panels as the power source to run this system. The waste management was carried out using the composting method. Five large composters $(150 \mathrm{~L})$ were distributed to the people in Sitanala to be used for the collective organic waste processing. In addition, 80 small waste cabinets ( $9 \mathrm{~L})$ were distributed to help the people in waste collection from individual houses. The evaluation of the program was carried out using a questionnaire to obtain the respondent's opinions about the program.

\section{Results and discussion}

The total number of RT 01/RW 13 Karangsari is 965 people, with 937 joining the door-todoor surveys and 200 being affected by leprosy. However, several of the population members were unavailable at home during the survey or refused to be interviewed. In addition to leprosy survivors and their families, several Sitanala Hospital medical staffs also live in the region. The characteristic population is normal, almost half of the population $(46 \%)$ is in productive age (16-55 years), and about one-third (30\%) is under 16 years. Most of the 
population members have social insurance $(87 \%)$, and a higher number is observed among the people affected by leprosy (94\%). Table 1 shows the characteristics of people affected by leprosy in the study.

Table 1. Characteristics of the Population and People affected by Leprosy in Study area 2019

\begin{tabular}{lrrrr}
\hline \multirow{2}{*}{ Characteristics } & \multicolumn{2}{c}{ Population(N=937) } & \multicolumn{2}{c}{ Leprosy $(\mathrm{N}=200)$} \\
\cline { 2 - 5 } Sex & $\mathrm{n}$ & $\%$ & $\mathrm{n}$ & $\%$ \\
Male & 485 & $52 \%$ & 119 & $60 \%$ \\
Female & 452 & $48 \%$ & 81 & $40 \%$ \\
Age group & & & & \\
$<5$ & 102 & $11 \%$ & 3 & $2 \%$ \\
$5-10$ & 93 & $10 \%$ & - & - \\
$11-15$ & 87 & $9 \%$ & 4 & $2 \%$ \\
$16-25$ & 161 & $17 \%$ & 2 & $1 \%$ \\
$26-35$ & 142 & $15 \%$ & 18 & $9 \%$ \\
$36-45$ & 130 & $14 \%$ & 42 & $21 \%$ \\
$46-55$ & 114 & $12 \%$ & 60 & $30 \%$ \\
$56-65$ & 70 & $7 \%$ & 47 & $24 \%$ \\
$65+$ & 38 & $4 \%$ & 24 & $12 \%$
\end{tabular}

\section{Education}

Did not go to school

196

$21 \%$

40

$20 \%$

Finished elementary education

79

$8 \%$

3

$2 \%$

Did not finish elementary

education

113

$12 \%$

48

$24 \%$

Completed elementary education

186

$20 \%$

55

$28 \%$

Did not complete junior high

school

$2 \%$

2

$1 \%$

Completed junior high school

156

$17 \%$

30

$15 \%$

Did not finish high school

$1 \%$

$0 \%$

Completed high school

152

$16 \%$

21

$11 \%$

Finished DI/DII/DIII

Finished DIV/S1/S2/S3

2

$0 \%$

$0 \%$

18

$2 \%$

1

$1 \%$ 
Characteristics

\begin{tabular}{rrrr}
\multicolumn{2}{c}{ Population $(\mathrm{N}=937)$} & \multicolumn{2}{c}{ Leprosy $(\mathrm{N}=200)$} \\
\hline $\mathrm{n}$ & $\%$ & $\mathrm{n}$ & $\%$
\end{tabular}

\section{Occupation}

\begin{tabular}{lrrrr} 
NA & 181 & $19 \%$ & 3 & $2 \%$ \\
Not working & 266 & $28 \%$ & 91 & $46 \%$ \\
Student & 116 & $12 \%$ & 4 & $2 \%$ \\
Civil servant/employee & 90 & $10 \%$ & 14 & $7 \%$ \\
Entrepreneur/services & 123 & $13 \%$ & 37 & $19 \%$ \\
Farmer & 4 & $0 \%$ & 3 & $2 \%$ \\
Labor & 121 & $13 \%$ & 34 & $17 \%$ \\
Others & 36 & $4 \%$ & 14 & $7 \%$ \\
Ownership of insurance & & & & \\
National government insurance & 818 & $87 \%$ & 188 & $94 \%$ \\
Other insurance & 5 & $1 \%$ & 1 & $1 \%$ \\
Don't have it & 114 & $12 \%$ & 11 & $6 \%$ \\
\hline
\end{tabular}

The data in Table 1 were implemented as the database of the leprosy population, which mostly comprised males $(60 \%, 119 / 200)$ and individuals in late adulthood (46-55 years old). This research is similar with another study from Malik \& Morris (2011) at the Hospital for Tropical Diseases, London, which reported that the leprosy population is dominates by male $(83 \%)$ and late adulthood individuals (40-77 years old with the mean age of 55-45). In addition, for the leprosy patients' education, the program revealed that $(46 \%, 91 / 200)$ did not receive a proper schooling program nor did not finish the elementary school either and (46\%, 91/200) unoccupied. Dabrera's study showed that most of leprosy patients receive less than 4 years of formal education, and $42 \%$ are jobless.

The level of jobless people with leprosy is higher compared with the general population. This situation is common among people with leprosy; it is related to a low education achievement, exclusion, low self-esteem, stigmatization, and discrimination (van Brakel, 2018). Losing an opportunity or job will devastate the family's social-economic status in the long term because they cannot contribute to the family welfare, especially for the productive age parents. This condition will raise other problems, such as spoiling the family bond, neglected child education, and affecting the food security for the family member, which 
probably can jeopardize the family health condition (Pescarini, 2018). Several leprosy people will use a shortcut to become beggars for life; others feel comfortable with this job and have become vulnerable to social problems in the community (Kaur et al., 2003). As found in India, begging for life has created the community's cultural view that leprosy patients must be a beggar, or being a beggar is the last choice for leprosy. However, if the person with leprosy do not finish the treatment, then they become a carrier of the disease (Krishnamurty, 1990; Rao, 2000).

Late adulthood presented the highest percentage in leprosy population. Nevertheless, a leprosy case was still observed at the age $<5$ years old $(2 \%, 3 / 200)$. This finding will be a great concern for the health program to give optimal medication for adult patients. Thus, early identification and treatment will prevent the spread to children. Moreover, the database about education prompted the program to give a simple and applicable approach. Thus, the patients can understand the approach well and apply it in their daily life.

\subsection{Eye health status}

The eye examination applied to all participants included leprosy patients along with their family with or without leprosy signs and diagnosis. Examination started with anamnesis of the patients about their eye health and symptoms. Visual acuity was classified based on World Health Organization (WHO): Vision Impairment Classification, with mild or no visual impairment of the visual acuity $\geq 6 / 18$, moderate visual impairment of the visual acuity < $6 / 18$ to $\geq 6 / 60$, severe visual impairment of the visual acuity $<6 / 60$ to $\geq 3 / 60$, and blindness of the visual acuity $<3 / 60$ to no light perception $(\mathrm{WHO}, 2018)$. Table 2 shows the patient database.

Table 2. Visual Impairment based on WHO Classification ( $N=304 ; n=608$ eyes)

\begin{tabular}{lllll}
\hline Classification of & \multicolumn{2}{c}{ UCVA } & \multicolumn{2}{c}{ BCVA } \\
\cline { 2 - 5 } Visual impairment & $\mathrm{n}$ & $(\%)$ & $\mathrm{n}$ & $(\%)$ \\
\hline Mild or no & 368 & 60.52 & 378 & 62.79 \\
Moderate & 147 & 24.17 & 26 & 4.2 \\
Severe & 36 & 5.92 & 6 & 0.98 \\
Blindness & 17 & 2.79 & 6 & 0.98 \\
N/A & 40 & 6.57 & 192 & 30.9 \\
\hline
\end{tabular}


The impairment of visual acuity was correlated to the condition of the anterior and posterior segments of the eye. A total of 304 subjects participated, but the posterior segment examination was performed on 106 patients who were suspected to have posterior segment abnormalities based on the visual acuity and anterior segment examination

Table 3. Anterior Segment Abnormality ( $\mathrm{N}=304 ; \mathrm{n}=608$ eyes)

\begin{tabular}{lll}
\hline Abnormality & $\mathrm{n}$ & $(\%)$ \\
\hline Cataract & 147 & 24.2 \\
Pterygium & 73 & 12.0 \\
Lagophtlhamos & 30 & 4.9 \\
Dermatochalasis & 24 & 3.9 \\
Meibomian gland dysfunction & 22 & 3.6 \\
Epitheliopathy & 19 & 3.2 \\
Corneal Ulcer & 18 & 2.9 \\
Corneal Scar & 11 & 1.9 \\
Entropion & 10 & 1.6 \\
Ectropion & 10 & 1.6 \\
Madarosis & 10 & 1.6 \\
Trichiasis & 9 & 1.5 \\
Keratic precipitate & 7 & 1.1 \\
Corneal injection & 3 & 0.5 \\
Iris synechiae & 2 & 0.3 \\
Tremorous Iris & 2 & 0.3 \\
Nevus on Eyelid & 1 & 0.2 \\
Tumor on Eyelid & 1 & 0.2 \\
Phthisis bulbi & 208 & 0.2 \\
Normal Eyes & & \\
\hline & & 34.2 \\
\hline
\end{tabular}

Table 4. Posterior Segment Abnormality (N=106; $\mathrm{n}=212$ eyes)

\begin{tabular}{lll}
\hline Abnormality & $\mathrm{n}$ & $(\%)$ \\
\hline Glaucomatous Papil & 10 & 3.2 \\
Myopic Crescent Papil & 10 & 3.2 \\
Diabetic Retinopathy & 5 & 1.6
\end{tabular}




\begin{tabular}{lll}
\hline Abnormality & $\mathrm{n}$ & $(\%)$ \\
\hline Pigment Changes & 2 & 0,6 \\
Retinal Detachment & 1 & 0.3 \\
Normal fundus & 284 & 91 \\
\hline
\end{tabular}

As shown in Table 3, the result of anterior eye health examination for 304 Sitanala's population was $34.2 \%$ with normal eyes, and the highest abnormality was cataract, followed by pterygium, lagophthalmos, and dermatochalasis. The abnormalities found are preventable and treatable, thus preventing visual impairment and blindness. Nevertheless, the patients needed an optimal vision. This program was followed by the treatment related to the patients' eye abnormality, ranging from giving them spectacles to improving visual acuity to elective surgeries, such as cataract, lagophthalmos, and pterygium removal, which was held one month after the screening examination. Several patients refused to have surgery. Surgical charity should be carried out periodically to overcome patients' eye disorders. As presented in Table 4, the posterior eye health examination showed that most of the population has normal fundus (91\%), and the other majority abnormalities found were glaucomatous and myopic crescent pupils. Both can be treated optimally with the right medication and routine follow-ups by the ophthalmologist.

The surgeries were performed for five lagophthalmos patients with techniques of gold weight implant or modified tarsorrhaphy with the condition. One and seven days after operation, one patient had a minimal lagophthalmos with a size of $0.5 \mathrm{~cm}$, and others had optimal improvement of the lagophthalmos condition. Pterygium removal was conducted for five patients with technique of pterygiumplasty and optimal graft condition on the first and seventh day after operation has been reached.

Furthermore, cataract surgery was performed for 10 patients with the technique of phacoemulsification, extracapsular cataract extraction, or intracapsular cataract extraction, following the cataract condition of each patient considering the benefits and risks individually (Olson, 2017). Cataract patients who underwent the surgery had improvement of visual acuity of up to $6 / 6$ on the seventh day after the surgery. The next follow-up of this program was coordinated with local health's facilities, such as Primary Health Center and hospitals near their area of settlement. 
Table 5. Demographic Data of Leprosy Patients who Followed the whole Program $(\mathrm{N}=117)$

\begin{tabular}{lcc}
\multicolumn{1}{c}{ Variable } & $\mathrm{n}$ & $(\%)$ \\
\hline Mean age (Mean \pm SD) & $51.2 \pm 10.5$ & \\
Gender & 64 & $(54.7)$ \\
Male & 53 & $(45.3)$ \\
Female & & \\
Duration of leprosy & 23 & $(19.7)$ \\
$<2$ year & 48 & $(41)$ \\
2-5 year & 8 & $(6.8)$ \\
$>5$ year & 38 & $(32.5)$ \\
Unknown & & - \\
Type of leprosy & - & - \\
Paucibacillar (PB) & - & $(100)$ \\
Multibacillar (MB) & 117 & - \\
Release/Non-active leprosy & - & \\
Unknown & & \\
Drop out & 117 & \\
Release from treatment & - & \\
Unknown & & \\
\hline
\end{tabular}

\subsection{Skin health status}

Participants who followed the comprehensive anti-stigma, economic, and health program comprised 304 people with 117 people diagnosed with leprosy. The mean age of leprosy patients was $51.2 \pm 10.5$ years with male and female proportion of $54.7 \%$ and $45.3 \%$ respectively (Table 5). Approximately $41 \%$ of patients were treated for leprosy for a duration of 2-5 years, whereas $32.5 \%$ was undetermined due to recall bias. All participants had completed their leprosy treatment regime.

Nail changes were observed through clinical examination and dermoscopy in 80 participants. Both fingernail and toenail abnormalities were found in all 80 participants (100\%). More than one nail abnormalities can be found in a patient. Twenty types of nail abnormalities were assessed in this study. However, we presented the three most frequent nail changes found with the following proportions, as summarized in Table 6. 
Table 6. Fingernail and Toenail Abnormalities Proportion in Leprosy Patients $(\mathrm{N}=80)$

\begin{tabular}{lll}
\hline & $\mathrm{n}$ & $(\%)$ \\
\hline Fingernails & 39 & 48.8 \\
Longitudinal ridging & 38 & 47.5 \\
Longitudinal melanonychia & 38 & 41.3 \\
Brittle nail & & \\
Toenails & 37 & 46.3 \\
Longitudinal ridging & 54 & 67.5 \\
Nail plate thickening & 38 & 47.5 \\
Subungual hyperkeratosis &
\end{tabular}

*n (the patients could have more than one abnormality on fingernails or toenails)

A limited number of studies observed nail changes in leprosy patients. The first one (Patki \& Baran., 1991), which was published in 1991, found nail abnormalities in $64 \%$ of 357 patients. In 2003, (Kaur et al., 2003) reported an overall prevalence of 77.3\%. El Darouti et al (2011) reported $86 \%$ of 115 patients presenting with nail changes in Turkey, and recently Ramos, Reyes, \& Belinchón (2013) found 10 old leprosy cases that had nail changes in the hands and/or feet.

Nail involvement can be found in three out of four leprosy patients. The factors associated with nail changes in leprosy are neuropathy, repeated trauma, vascular impairment, repeated infections, or adverse effects from the drugs used in leprosy treatment, such as clofazimine or dapsone (Ramos, Reyes, \& Belinchón, 2013). Nail abnormalities in leprosy are usually secondary to distal resorption of the phalanges (Romero, Rincón, \& Rabell, 2012).

Ramos reported longitudinal striae, pseudoclubbing, and longitudinal melanonychia are the main changes found in fingernails, whereas onycholysis, brachyonychia, and onychauxis acted as the main changes found in toenails (Ramos, Reyes, \& Belinchón, 2013). Furthermore, Kaur et al. (2003) reported longitudinal melanonychia to be the most frequently found fingernail changes in $\mathrm{PB}$ and $\mathrm{MB}$ types. This result is similar to our findings, of which longitudinal melanonychia was one of the most frequently found fingernail changes in the participants. In contrast to this study, the participants were not divided based on their leprosy type; all were released from treatment years ago, and thus, diagnosis based purely on recall memory is unreliable. 
Any nail changes may be caused by diseases directly affecting the nail unit or as a part of a systemic disease (Romero, Rincón, \& Rabell, 2012). Nail changes are not specific to leprosy and can be found in other peripheral neuropathies, such as diabetes mellitus (Ramos, Reyes, \& Belinchón, 2013). Still, observation of these changes is vital for reevaluating the consequences elicited by leprosy, which consist of patient's physical, psychological, and social wellbeing.

\subsection{Extremity abnormalities}

Disabilities in leprosy are classified as grade 0 for no anesthesia and no visible deformity, grade 1 for anesthesia present but with no visible deformity, and grade 2 for visible deformity or damage. This WHO disability grading is commonly used in to evaluate the physical condition of leprosy. Disabilities often result in more defects than physical dysfunction and include activity limitations, stigma, discrimination, and social participation restrictions (Kemenkes, 2012; WHO, 2018). Overall, 124 patients with a leprosy-related disability were identified, but 7 participants did not follow the procedure completely. Seven people dropped out because of missing value. Thus, the final data for 117 people were obtained. Exactly $17.9 \%$ of the patients had a grade 2 degree of impairment of scars of healed ulcers, decreased sensation, and muscle weakness but showed no joint contracture (Table 7). The degree of physical impairment is related to social problems and stigma (Figure 2).

According to WHO, disability is an umbrella term covering impairments, activity limitations, and participation restrictions. Examples of how to describe disabilities in leprosy patients and survivors are given in this paper. Impairment is a problem in a body function or structure. Hand deformity is an example of a body structure problem in leprosy patients. The deformity is primarily due to peripheral nerve lesion, mostly in ulnar and median nerve, caused by Mycobacterium leprosy infection. This condition leads to hand function problems, such as weakness, analgesia, and sensory perception disturbance. Activity limitation is a difficulty encountered by an individual in executing a task or action. Basic activity daily living dependency is the example of activity limitation. Leprosy patients and survivors with hand deformity and weakness usually experience limitations in basic daily activities, especially when the impairments occur in their dominant hand (Rajan, 2005). Participation restriction is a problem experienced by an individual in life situations. Most of leprosy survivors had restricted participation in job hunting, marriage, and housing. 


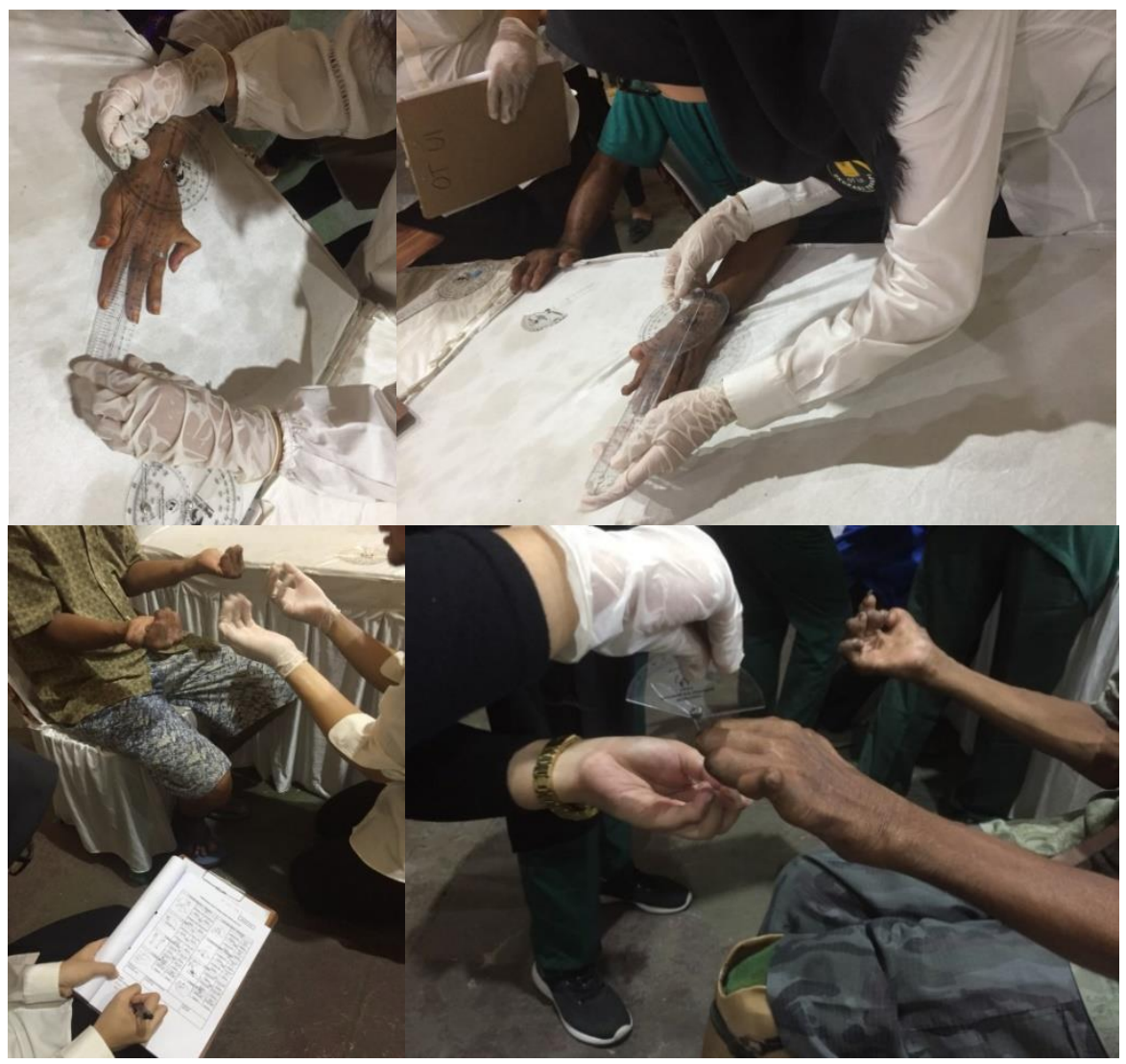

Figure 2. Physical assessment of upper extremity of leprosy villagers in Sitanala

From the previous description, leprosy is prone to cause impairment, activity limitation, and participation restriction. The participants were referred to medical rehabilitation if they showed activity limitation and participation restriction. From the description, impairment leads to activity and participation limitation, but in real life situations, the case may be different. The impairment of organs will affect their function (Gopa, 2016), but the impairment is not correlated with activity limitation and participation restriction which may be due to compensation mechanisms or other factors (Reis, 2017). However, such information presents hope in managing leprosy disability.

Using the rehabilitation principle of participation limitation, the medical rehabilitation team designed art activities for leprosy villagers in Sitanala. Art activities were selected because they are one of the strategies used to yield new insights and acceptance by doing art activity (Hasnain, 2020; Reis, 2017). Thus, we asked the participants to create a painting with their impaired hand. Several refused because of their lack of confidence. Then, it was proven oppositely, given that most of participants can paint, even for those with severe deformity (Figure 3). We hope that this kind of activity will develop into larger projects, such as sports, 
painting, or national art competitions or festivals, especially for leprosy survivors. Thus, the spirit of productivity, despite the impairment of leprosy patients, has been widely spread.
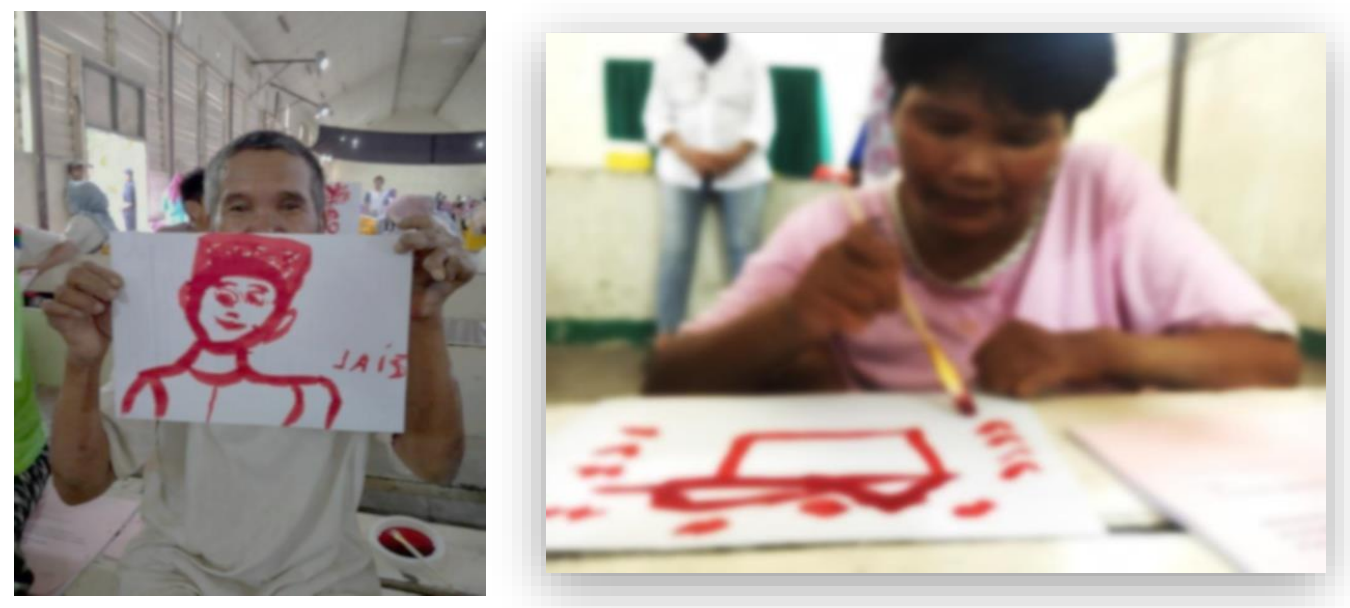

Figure 3. Medical rehabilitation team designed art activities for leprosy villagers in Sitanala.

In addition, we can implement actions, such as medical rehabilitation and administration of orthoses and prostheses, to increase the mobility and productivity of the patient. Promotional activities were carried out in the form of leprosy seminar to leprosy patients and their families to prevent further disability in the patient's extremities and eyes.

Table 7. Extremity Abnormalities ( $\mathrm{n}=117)$

\begin{tabular}{lll}
\hline Abnormality & $\mathrm{n}$ & $(\%)$ \\
\hline Grade 0 & 8 & 6.8 \\
Grade 1 & 88 & 75.2 \\
Grade 2 & 21 & 17,9 \\
Functional Level & & \\
Mild or no & 73 & 62.39 \\
Moderate & 40 & 34.1 \\
$\quad$ Severe & 4 & 3.4 \\
$\quad$ Dependent & NA & NA \\
Stigma problems & & \\
Low or no & 53 & 45.29 \\
Mild & 42 & 35.89
\end{tabular}




\begin{tabular}{lll}
\hline Abnormality & $\mathrm{n}$ & $(\%)$ \\
\hline Moderate & 12 & 10.25 \\
Severe & 10 & 8.5 \\
\hline
\end{tabular}

\subsection{Oral hygiene status}

A total of 119 participants agreed and signed the informed consent for oral hygiene examination in this study. The results of oral hygiene examination showed that most of the participants had poor $(62,52.1 \%)$, moderate $(47,39.5 \%)$, and good $(5,4.2 \%)$ oral hygiene. Brushing of the teeth is a part of basic daily living activities. The research by Ferrira et al. on the elderly with a history of leprosy stated that from 74 study participants, 53 (71.6\%) were completely independent, $12(16.2 \%)$ were partially dependent, and 9 (12.2\%) were completely dependent on others for brushing their dentures.

The inability to maintain oral health and hygiene in leprosy patients is mostly related to physical deformities, especially in the fingers and hands (Ferreira et al, 2018). Matos et al. (2018) research in India stated that the oral health status of leprosy patients was poor and required treatment. This result may be due to peripheral neuropathy and hand deformities that impede oral hygiene (Matos et al., 2018). Abnormalities in the oral cavity of leprosy patients in hard and soft tissues can be specific or unrelated manifestations of the leprosy they suffer from. However, they can also be related to the inability of patients to maintain oral hygiene due to defects in innervation or physical disability that inhibits activity.

\subsection{Psychological aspects}

The sample was randomized from 304 patients, and 107 selected patients who were diagnosed with leprosy or family members of leprosy patients were included for psychological examination. The physical disabilities of the patients affected their psychological health. We observed that $62.5 \%$ of the patients experienced a significant distress, whereas a value as large as $37.5 \%$ was observed in the family group. Females experienced higher psychological distress than males. This result is in line with that of previous studies (Dijkstra, Brakel, \& Elteren, 2017; Islam, 2019; Zhang et.al., 2018). Meanwhile, the psychological distress rate was lower in participants who had family support. From the findings in this data processing, several things can be discussed and serve as the basis for the preparation of interventions in the second phase of activities. Data showing that family groups experience more 
psychological distress than the patients can be an indication that their family may be experiencing burnout in carrying out the role of a support.

The family probably experiences burnout, which is widely known as "caregiver burnout" (Scharlach et al., 2016), that results from the inability of the patient to carry out their physical activities. This situation has also forced several patients not to send their children to school to help at home. Their children eventually had to earn money to meet the family's economic needs, such as by selling goods at the road crossings, serving as a garbage transporter, or busking. The pressing economic issues reinforce the pressure from the family because of the oppressed needs. However, on the patient's side, family support is their strength.

Table 8 shows that the majority of participants in this study were females $(91,59 \%)$, and in Table 9, the average HSCL-25 score of participants was below the cut-off value of 1.52, with a minimum value of 0.96 and a maximum of 3.12. A total of 40 participants (26\%) had levels of psychological distress above the cut-off. As many as 25 participants $(62.5 \%)$ who have psychological distress were residents who suffered from leprosy, whereas as many as 15 participants $(37.5 \%)$ were family sufferers.

Table 8. Demographics of the participants

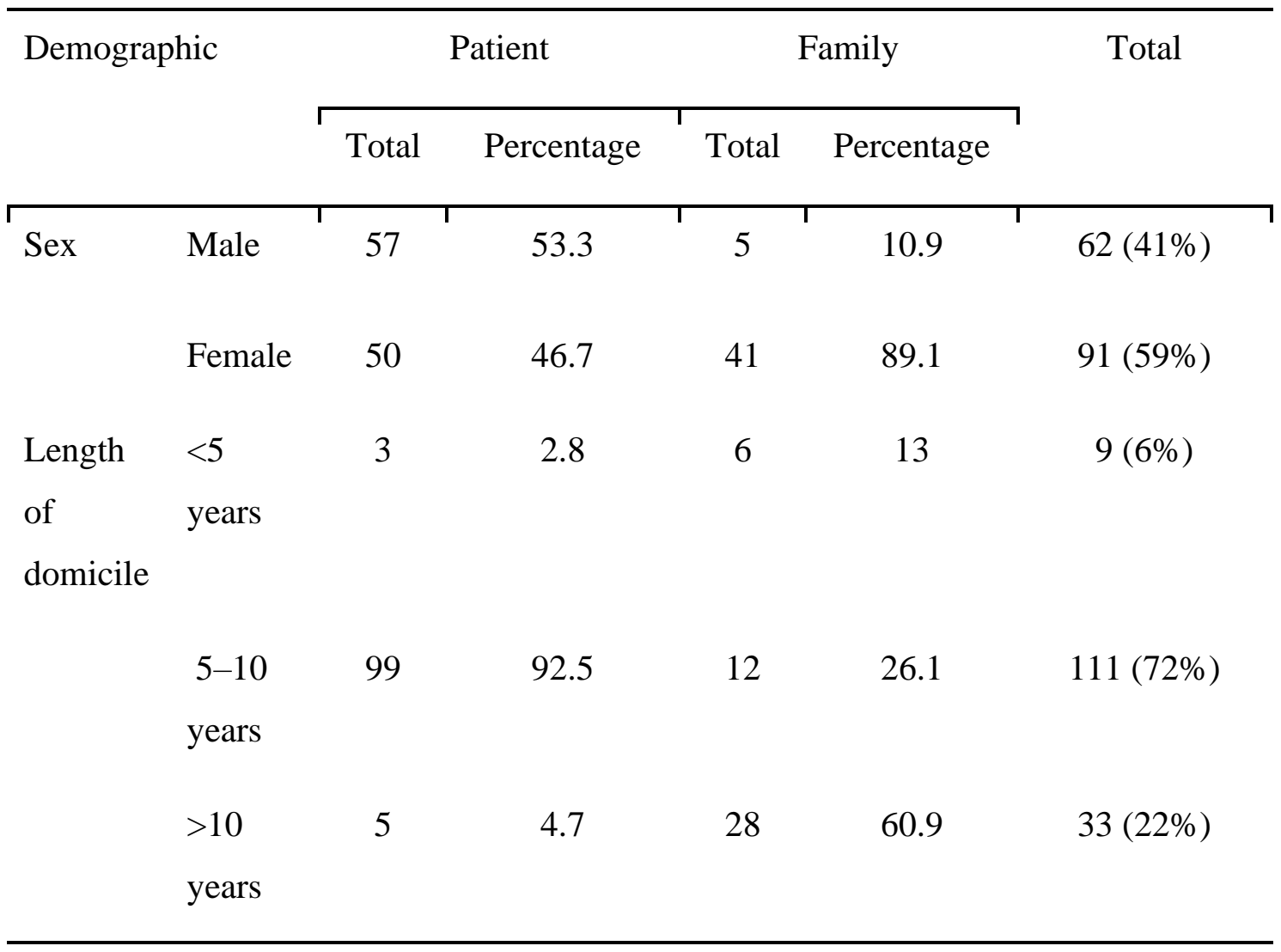


Table 9. Psychological distress of Sitanala residents

\begin{tabular}{|c|c|c|c|c|c|c|c|}
\hline & Mean & Min & Max & $\begin{array}{l}\text { Above } \\
\text { Cut- } \\
\text { off }\end{array}$ & $\begin{array}{c}\text { Mean } \\
\text { Differences }\end{array}$ & $\begin{array}{c}\text { t-statistic } \\
\text { (df) }\end{array}$ & $P$-value \\
\hline $\begin{array}{l}\text { Participants } \\
\text { in total }\end{array}$ & 1.52 & 0.96 & 3.12 & $40(26 \%)$ & & & \\
\hline Patients & 2.21 & 1.76 & 3.12 & $\begin{array}{c}25 \\
(62.5 \%)\end{array}$ & 0.02 & $\begin{array}{l}0.55 \\
(151)\end{array}$ & 0.58 \\
\hline $\begin{array}{l}\text { Family of } \\
\text { Patients }\end{array}$ & 2.23 & 1.76 & 3.12 & $\begin{array}{c}15 \\
(37.5 \%)\end{array}$ & & & \\
\hline
\end{tabular}

The families of patients showed a slightly higher average level of psychological distress compared with the patients themselves. Still, a statistical analysis was performed to determine significant differences between the two groups ( $t$-test). The results showed no significant difference in psychological distress $(t=0.55, p>0.05)$. In addition, people with leprosy who feel unsupported by anyone present the highest level of psychological distress compared with those who feel the support of their family and/or neighbors. Still, the results showed significant differences in the psychological distress among the three groups $(\mathrm{F}=2.19, \mathrm{p}>$ $0.05)$.

\subsection{Social and cultural aspects}

Based on the qualitative data, the leprosy survivors were ex-patients of Sitanala Hospital and came from different regions of Indonesia. Around the early 80s, they obtained permission to stay in the hospital housing complex, and to date, more than three generations are living in the housing complex. As leprosy survivors, their access to economic resources are limited. Therefore, several of them are begging until now. Interestingly, their children as the second generation and grandchild as the third generation are healthy. The second generations are more educated, who are graduated from a vocational school. Nevertheless, access to the labor market is limited when a leprosy child is stigmatized in social relations.

A case involved a girl who failed to marry when her leprosy family background was revealed. In dealing with social stigma, young men are indifferent, in contrast to the group of 
young women. However, both groups hope that their children (the third generation) will no longer live with the stigma.

Social cohesion is weak, particularly among leprosy survivors, as proven by the former head of the neighbourhood association. He stated that such condition may be due to his busy working life. Moreover, given their physical condition, the survivors are reluctant to participate or join in social and religious activities. The condition is also reflected by their children. Young people claim that they only gather on the Indonesian Independence Day and or Islamic holidays. From the sociological aspect, the social capital of the Sitanala community is weak and needs more efforts to build togetherness in the community.

\subsection{Agro-economic aspects}

The health status affects the person's quality of life. As an effort to increase the economic capacity of the leprosy community in Sitanala, our team conducted a series of programs to cultivate their area through hydroponics and the management of their organic waste. The program consisted of the installation of the NFT hydroponic system along with solar panels, the introduction of hydroponic and household waste processing through interactive training and examples, and hands-on follow-up with the assistance of hydroponic and waste processing. Hydroponics refers to the process of growing plants without soil but in water enriched with nutrients and oxygen.

According to the interview, most of the participants had experience in small farming on lands, and several of them are land laborers. However, none of them had prior knowledge about hydroponics. In this program, they were taught how to grow vegetables, such as water spinach, lettuce, etc., using the hydroponics by NFT, which is a hydroponic technique wherein a shallow stream of water containing all the dissolved nutrients required for plant growth is recirculated past the roots of plants in a channel. The nutrients are mixed accordingly in a primary reservoir from which they flow through the system, continuously feeding the plants (Mohammed \& Sookoo, 2016). This method is advantageous in terms of the effective use of limited areas. In addition, by using this method, more people will be involved in the program. The system was installed using solar power. Thus, the people in Sitanala are not required to provide electricity for this hydroponic system. The participants were enthusiastic to learn and cultivate vegetables using hydroponics. Figure 4 depicts the hydroponic system with solar panels. 


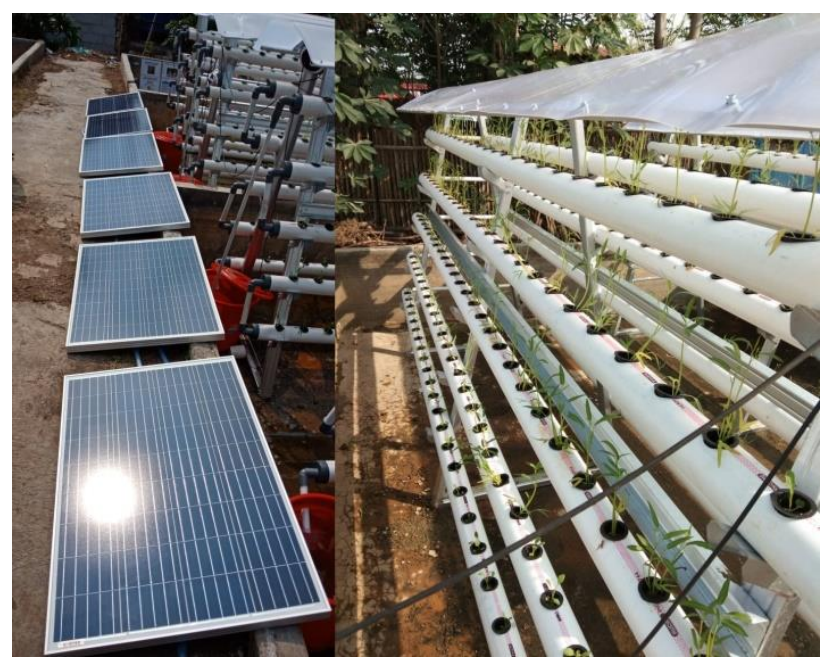

Figure 4. Hydroponic system with solar panels in Sitanala

The second program, i.e., organic waste processing, was carried out using the composting method. Waste is one of the problem sources for various fields, including health and the environment (Alam \& Ahmade, 2013; Chadar \& Chadar, 2017). To date, the wastes produced daily by the people in Sitanala are commonly thrown away directly. These wastes can be converted into various useful products and give a high economic value if marketed (Amasuomo \& Baird, 2016). In this program, the waste cabinet and composters were provided by the team for the participants. The people collected household organic wastes in the cabinet, and the wastes were further compiled in the composters for the composting process. The composter has a small cap at the bottom to receive the liquid fertilizer (leachate) resulting from the composting process, in addition to the solid fertilizer. The production of liquid fertilizer from organic waste processing is beneficial as nutrients for hydroponics. Thus, these programs (hydroponic and organic waste processing) are practical, valuable, and has potential to be carried out by people with leprosy in Sitanala in a sustainable manner.

The evaluation of the program was carried out using a questionnaire to obtain the respondents' opinions about the program. In the preliminary step, the organic fertilizer, vegetables, and composter produced from their activities are only used for themselves, but they have the potential to be marketed in the near future. The outcomes of the program are defined as the community's motivation to broaden their knowledge of hydroponics and waste processing and their willingness to continue hydroponics and waste processing after the program is over. Three months following the first program, the team visited Sitanala to monitor the progress and discuss the challenges faced by the people. A group of 10 people was defined to organize this agro-economy program. On the second occasion, the team also 
trained the young men (aged 20-35 years old) in Sitanala to create a composter on their own. This step increased the skills of the people with leprosy in Sitanala and added promising value to increase their input once the products are marketed.

At the end of the program, the participants were motivated to continue hydroponics and organic waste processing on their own. Furthermore, according to this program, the implementation of collaboration between different faculties is important to the success of the program, which can be duplicated in other areas as a model of community empowerment.

The data from the multicenter fulfilled each other, and the demographics showed each datum based on their domicile status, which is very useful in categorizing the health status of families, including the status of patients, close contact relatives, or a healthy population. These groupings were followed by the examination of physical and physiological health status as the database for further intervention. Leprosy patients, including those with moderate-to-severe disabilities of the eyes, underwent an operation one month after the screening examination. The relatives with a close contact received prevention therapy, and leprosy members of the society, especially those with hand or foot disabilities and physical limitations, received training about cultivation and waste processing and their economic and practical value. The anti-stigma, health, and economic teams collaborated to optimize the quality of life and increase the community welfare status of leprosy patients.

Reflecting on the study and interventions that have been carried out, further management is still needed to improve the standard of living of the population. Improved health status and reduced stigma in society toward leprosy patients and their families can increase their selfconfidence of them and help them easily find jobs. The development of skill training can create new jobs and increase their productivity. This condition can increase the economic situation and quality of life of the community. From the demographic data above, coordination with policy makers regarding the handling of leprosy patients and their families can be achieved in the form of education guarantees for children from leprosy patients or skills training for leprosy patients which is coordinated with the Ministry of Health, Ministry of Education, and Ministry of Manpower.

\section{Conclusion}

As part of the whole program, a collaboration of faculties in Universitas Indonesia that joined together as KATAMATAKU can comprehensively improve the quality of life of the people with leprosy in Sitanala from every aspect including health, social, and economy. A model for the leprosy program with multidimensional collaboration is highly effective on physical 
disabilities, and the psychological effect causes the patient to accept that the program is suited their condition and needs.

The coordination and collaboration with hospital staff and local community leaders are highly efficient. The implementation of this multidisciplinary community engagement program at Sitanala settlement can improve the health, social, and economic status of leprosy patients. However, this program needs continuation until the leprosy community establishes better life in all aspects. This program is the first multidimensional program and can be duplicated in other areas as a model of community empowerment.

\section{Acknowledgment}

We thank all the participants, especially the residents of RT 01 RW 13 Sitanala settlement village. We also acknowledge Sitanala Hospital, Topcon Industries, and Cendo Company for their medical equipment and medicamentous support, and Directorate P2 of Direct Transmitted Disease Director General P2P Health Ministry of Indonesia (Seksi Kusta dan Frambusia/Direktorat Penyakit Tropis Menular Langsung/Direktorat P2 Penyakit Menular Langsung/Ditjen P2P Kementerian Kesehatan RI).

\section{Funding}

This work was supported by the Community Engagement Grant of 2019, Directorate of Research and Community Engagement Universitas Indonesia.

\section{Declaration of Conflicting Interest}

There is no conflicting of interest for this manuscript.

\section{Author Contribution}

Each author contributed to this work. Yunia Irawati, Tri Rahayu, Sri Linuwih SW Menaldi, Melinda Harini, Luh Karunia Wahyuni, Wanarani Alwin, Astari Dwiranti, Adhityawarman Menaldi, Dadun, Rico Kurniawan, Ida Ruwaida, Gunawan Wicaksono M.H. Sahid, and Febrina Rahmayanti contribute to the design, methodology, collect data, and investigation of the work. Sonny Tirta Luzanil, Qaishum Matsurah, Florentina Priscilia, and Anis Fitriana contribute to collect data, analysis, and project administration. Furthermore, Yunia Irawati, Hisar Daniel, and Yeni Dwi Lestari contribute to review, edit, and supervise this manuscript. Made Susiyanti, Gitalisa Andayani, and Anna Puspitasari Bani contribute to write, compile, and edit English manuscript. 


\section{Short Biography}

Yunia Irawati has been a consultant for Ophthalmology Department, Faculty of Medicine, Universitas Indonesia - Cipto Mangungkusumo General Hospital (UI - RSCM) and JEC Eye Hospitals and Clinics, Jakarta since 2004. She graduated as a General Practitioner in 1992 and as an Ophthalmologist in 2003, at Universitas Indonesia. Joined the program as an Observer at Moorfields Eye Hospital London and Singapore National Eye Center in 2007. Joined Adnexal and Orbital Fellowship Program at Seirei Hamamatsu Hospital, Japan. Yunia's clinical and research interest focus on eyelid reconstructive surgery, orbital socket and fracture reconstruction, and lacrimal excretion system surgery.

Sri Linuwih SW Menaldi graduated as a Dermatologist in 1992. She joined the Dermatology and Venereology Department, Universitas Indonesia - Cipto Mangunkusumo General Hospital as a teaching staff since 1994. Having earned her Doctorate Degree in Medical Education from Universitas Gadjah Mada in 2013, she is also a teaching staff in the Medical Education Department. Since 1994 to 2014, she mostly works with medical undergraduates. In the leprosy field, Dr Menaldi is one of the leprosy expert commission at Indonesia's Ministry of Health and at Netherland Leprosy Relief (NLR) Indonesia. In the professional organization, she is currently the Head of Indonesia's Leprosy Study Group.

Melinda Harini has been medical staff of Geriatric Division of Physical Medicine and Rehabilitation Study Program, Faculty of Medicine, Universitas Indonesia - Cipto Mangungkusumo General Hospital (UI - RSCM) and Jakarta Port Hospital, Jakarta, since 2015. She graduated as a General Practitioner in 2006 from Diponegoro University and as as Physiatrists in 2015 from Universitas Indonesia. Joined clinical course program at National Taiwan University Hospital for Musculoskeletal Ultrasounography and Cardiac Rehabilitation in 2017. She graduated from geriatric rehabilitation consultant of Indonesian Physical Medicine and Rehabilitation Collegium in 2020. Her clinical and research interest focus on cardiac, geriatric, and covid rehabilitation.

Luh Karunia Wahyuni has been Head of Physical Medicine and Rehabilitation Department, Cipto Mangunkusumo General Hospital - Faculty of Medicine, Universitas Indonesia (RSCM-FKUI) since 2018 and Pediatric Consultant in Physical and Medicine Rehabilitation in RSCM-FKUI since 2010 and RSIA Bunda Jakarta. She graduated as General Practitioner in 1987 and as Physiatrists in 1996 from Universitas Indonesia. Joined program client 
centered rehabilitation Amsterdam in 2000, Visiting Scholar (Speech Pathology) of the Craniofacial Center at Chang Gung Memorial Hospital, Taipei, Taiwan in 2005. Luh's clinical and research interest focus on pediatric and neuromuscular rehabilitation.

Wanarani Alwin is medical staff of Geriatric Division of Physical Medicine and Rehabilitation (PM\&R) Study Program, Faculty of Medicine, Universitas Indonesia - Cipto Mangungkusumo General Hospital (UI - RSCM). She had become Research Coordinator, Head of Geriatric Rehabilitation Division and Head of Department of PM\&R UI-RSCM. She is now a chairman of Geriatric Special Interest Group of Indonesia PM\&R Association (PB PERDOSRI), 1st chief of Indonesia Wellness Master Association (IWMA), Head of the Education Division of ISWI (Ikatan Sarjana Wanita Indonesia), and Head of the Health Division of Indonesian Archery Association (PB PERPANI). Her clinical and research interest focus on falls and cognitive rehabilitation, caregiver management, and aging.

Astari Dwiranti is a lecturer and researcher at the Department of Biology, Faculty of Mathematics and Natural Sciences. She graduated from Bandung Institute of Technology majoring in microbiology and gained her Master and Doctoral degree from Osaka University, Japan majoring in Biotechnology. Her expertise is in cellular and molecular biology, especially cytogenetics. She also has an interest in environmental issues and had experienced in the waste management community engagement programs.

Adhityawarman Menaldi is a clinical psychologist who focuses on research and interventions related to health behavior. He completed his clinical professional education in 2008 and has joined the Faculty of Psychology Universitas Indonesia as a lecturer ever since. Apart from being a full-time teacher and researcher, he also practices as a clinical psychologist. The beginning of his practical journey began as a clinical psychologist at the Diatrans Indonesia Kidney Foundation. $\mathrm{He}$ is also often involved in empowering healthcare workers and counselors in TB programs in Indonesia.

Sonny Tirta Luzanil has been a student support officer for Universitas Multimedia Nusantara, Tangerang since June 2021. He graduated as a Bachelor of Psychology in 2016 and as a Clinical Psychologist in 2021, at Universitas Indonesia. Since graduate from master's degree, he became a counselor at Research of Community Mental Health Initiative (Rocmhi) 
provides counseling in online session. Sonny has clinical and research experience in anxiety, depression, conducts problems, and academic problems.

Qaishum masturoh is a clinical psychologist from Indonesia. In 2016 she finished her bachelor's degree in psychology from Universitas Indonesia. She got her master's degree in 2021 from Faculty of Psychology Universitas Indonesia. She has been an active member of Research of Community Mental Health Initiative since 2020 and provides free online counseling for people in needs. In 2021 she joined Mind Institute, Impruv and Psylution as an associate psychologist who provides psychoeducation and counseling.

Dadun, graduated from public administration and health economic public health Universitas Indonesia. He earned Doctor in social science from Faculty of earth and life science Vrije University Amsterdam in 2017. He is senior researcher at center for health research universitas Indonesia. He is currently working on public health areas, health related stigma and disability issues.

Rico Kurniawan is a public health and health information systems expert with many experiences conducting health research and developing information systems for health programs. Besides being a lecturer at the Department of Biostatistics and Population Study, Faculty of Public Health, Universitas Indonesia, he also actively conducts research and develops health information systems for health programs at the national and local levels. Moreover, he also works closely with the government and international agencies such as Global Fund, University Research (URC), and Guttmacher Institute to evaluate health programs such as health information system, HIV, TB, Malaria, and Maternal and Child Health programs. Mr. Kurniawan has a research interest in biostatistics, health informatics, and health information system.

Ida Ruwaida is a lecturer at the Department of Sociology, Faculty of Social and Political Sciences, Universitas Indonesia. Since an undergraduate student, Ida has been involved in a number of research and community engagement activities at LabSosio (Sociological Studies Unit). She is also active in the Gender and Sexuality Studies Unit. In the Department of Sociology, Ida was assigned to be the coordinator of the research cluster "Family, Gender, and Social Transformation". Agenda of research cluster is focusing on issues of "family and 
child well-being". Ida's own studies focus mostly on women, gender and the economy, including community development.

Gunawan Wicaksono, A.Md.OT, SKM, M.Si, has completed his occupational therapy diploma at the Universitas Indonesia in 2004 and continued his undergraduate education in the Department of Public Health Nutrition, Faculty of Public Health, Universitas Indonesia in 2006. Gunawan continued his master's studies at the Universitas Indonesia majoring in Health Psychology and successfully graduated in 2011. In 2015, Gunawan continued his doctoral education majoring in Occupational Therapy at Tokyo Metropolitan University and is still running today.

Muhammad Hidayat Sahid completed diploma in occupational therapy at the Surakarta Health Polytechnic (2002) and continued bachelor at the Faculty of Public Health, Muhammadiyyah University (2009), then graduated master in the Clinical Epidemiology at the University of Indonesia (2018). Currently, actively becoming lecturer at the Occupational Therapy, Vocational, University of Indonesia study program in 2016.

Febrina Rahmayanti has been a lecturer and consultant for Oral Medicine Department, Faculty of Dentistry, University of Indonesia, Jakarta since 2003. She graduated as a dentist in 1997, as an oral medicine specialist in 2003, and completed her doctoral program in dentistry in 2017. Dr. Febrina is also an oral medicine specialist at the dental specialist clinic in RSPI Pondok Indah Jakarta since 2017. Febrina's clinical and research interests focus on infectious diseases in the oral cavity, management of oral diseases/manifestation in immuno/medically compromised patients, medicinal plants and special needs dentistry. She has received several research grants and intellectual property rights as well as publications in reputable journals both national and international.

Florentina Priscilia is a research assistant at Department of Ophthalmology dr. Cipto Mangunkusukmo Hospital Jakarta and a general practitioner at private hospital Jakarta. She received a bachelor's degree in Universitas Gadjah Mada as top 10 students. She interested in ophthalmology, public health, and community empowerment. As the part of her passion, she joined the committee for KATAMATAKU which held the continuing program for leprosy patient about their health and other aspects of life. 
Anis Fitriana is a research assistant at Department of Ophthalmology, Cipto Mangunkusumo General Hospital Jakarta and a general practitioner at a private hospital in Jakarta. She obtained her medical doctor degree at Universitas Brawijaya in 2017. Joining Katamataku allowed her to develop her interest in ophthalmology and public health services."

Tri Rahayu has been a consultant for Ophthalmology Department, Faculty of Medicine, Universitas Indonesia - Cipto Mangungkusumo General Hospital (UI - RSCM) and JEC Eye Hospitals and Clinics, Jakarta since 2001. She graduated as a General Practitioner in 1990 and as an Ophthalmologist in 2001, at Universitas Indonesia. Joined The International Association of Contact Lens Educator since 2001 and get Fellowship of International Association of Contact Lens Educator (FIACLE) in 2004. She gets achievement Lifetime FIACLE in 2018.

Made Susiyanti has been a consultant for Division of Infection and Immunology, Department of Ophthalmology, Faculty of Medicine, Universitas Indonesia-Cipto Mangunkusumo General Hospital (UI-RSCM) and JEC Eye Hospitals and Clinics Jakarta since 2007. She graduated as a General Practitioner in 1993 and as an Ophthalmologist in 2003 from Universitas Indonesia. She also graduated with a $\mathrm{PhD}$ degree in Biomedicine from Universitas Indonesia in 2018. She had undertaken Cornea and External Eye Disease fellowship training at Singapore National Eye Center in 2006-2007. Her clinical and research interest are focused on infection and immunology, cornea, and external eye disease.

Gitalisa Andayani Adriono is a vitreo-retina consultant at the Department of Ophthalmology, Faculty of Medicine, University of Indonesia (affiliated with Cipto Mangunkusumo Hospital), Jakarta, since 2008, and JEC Eye Hospitals and Clinics since 2005. She graduated as a General Practitioner in 1992 and as an ophthalmologist in 2003, from University of Indonesia. She underwent her vitreoretina clinical fellowship from the National Healthcare Group Eye Institute, at Tan Tock Seng Hospital, Singapore, in 2009. She completed her medical science doctorate program from University of Indonesia in 2018. Her clinical and research interest focus on diabetic retinopathy, posterior segment trauma and retinopathy of prematurity.

Anna Puspitasari Bani is currently a Medical Staff at Kirana Ciptomangunkusumo National Teaching Hospital and Faculty Member of Universitas Indonesia (FKUI), Ophthalmology 
Department. Finishing her undergraduate from the same university in 1995 and serving governmental service in West Nusa Tenggara as a medical professional, she continued to residency training in ophthalmology and graduated as a specialist from FKUI in 2007. Anna's clinical subspecialization is in strabismus for pediatrics and adults, with particular interests in binocular single vision, extraocular muscle basic sciences, strabismic patient's quality of life, amblyopia, and heavy eye syndrome. And as a continuing effort to further enhance understanding and practice, chances to join fellow-observerships at Moorfield's Eye Hospital London and NUH Singapore were all pursued.

Hisar Daniel graduated as a General Practitioner from Faculty of Medicine University of Indonesia in 2008 and complete his ophthalmology recidency program at the Faculty of Medicine University of Indonesia in 2018. He took further study in Oculoplastic, Oncology and Reconstructive Surgery at Ciptomangunkusomo Hospital, Jakarta in 2020. He was active as attendant in scientific meeting, and active on scientific publication. Hisar Daniel,MD is a staff of Oculoplastic, Oncology and Reconstructive Surgery Division at Ophthalmology Department Ciptomangunkusumo Hospital. Currently, he is an active member of IOA (Indonesian Ophthalmologist Association), INASOPRS (Indonesian Society of Ophthalmic Plastic and Reconstructive Surgery).

Yeni Dwi Lestari, MD is an ophthalmologist at Cipto Mangunkusumo Hospital (RSCM). She completed her residency in Universitas Indonesia (UI) and holds a master's degree in Public Health for Eye Care from London School of Hygiene and Tropical Medicine, UK, and is a doctoral candidate in UI. Currently, she is the head of Community Ophthalmology Department in FMUI/RSCM, a part of International Relationship Officer of IOA, serves as an editor at Ophthalmologica Indonesiana Journal, and was the former General Secretary of Indonesia National Committee of Prevention of Blindness (Komatnas). Her research interest centres around community eye health.

\section{References}

Alam, P., \& Ahmade, K. (2013). Impact of solid waste on health and the environment. International Journal of Sustainable Development and Green Economics (IJSDGE), 2(1), 165-168. https://intelligentjo.com/images/Papers/general/waste/IMPACT-OFSOLID-WASTE-ON-HEALTH-AND-THE-ENVIRONMENT.pdf 
Amasuomo, E., \& Baird, J. (2016). The concept of waste and waste management. Journal of Management and Sustainability, 6(4), 88-96. https://econpapers.repec.org/RePEc:ibn:jmsjnl:v:6:y:2016:1:4:p:88-96

Astutik, E., \& Gayatri, D. (2018). Perceived stigma in people affected by leprosy in leprosy village of Sitanala, Banten, Indonesia. Kesmas: Jurnal Kesehatan Masyarakat Nasional (National Public Health Journal), 12(4), 178-186.

http://dx.doi.org/10.21109/kesmas.v12i4.1756

Centers for Disease Control and Prevention. (1997). Principles of community engagement (1st ed). Atlanta (GA): CDC/ATSDR Committee on Community Engagement.

Chadar, S. N. \& Chadar, K. (2017). Solid waste pollution: A hazard to environment. Recent Advances in Petrochemical Science, 2(3), 41-43.

Clinical and Translational Science Awards (CTSA). (2011). Principles of Community Engagament: Second Edition. NIH Publication No. 11-7782.

Dabrera, T. M. E., Tillekeratne, L. G., Fernando, M. S. N., Kasturiaratchi, S. T. K., \& Østbye, T. (2016). Prevalence and Correlates of Leprosy in a High-Risk Community Setting in Sri Lanka. Asia-Pacific Journal of Public Health, 28(7), 586-591. https://doi.org/10.1177/1010539516666360

Dijkstra, J. I. R., Brakel, W. H. V., \& Elteren, M. V. (2017). Gender and leprosy-related stigma in endemic areas: A systematic review. Leprosy review, 88, 419-440. https://leprosyreview.org/article/88/3/41-9440

El Darouti, M. A., Hussein, S., Al Tahlawy, S. R., Al Fangary, M., Mashaly, H. M., El Nabarawy, E., ... \& Abdel Hay, R. M. (2011). Clinical study of nail changes in leprosy and comparison with nail changes in diabetic patients. Journal of the European Academy of Dermatology and Venereology, 25(3), 290-295. https://doi.org/10.1111/j.14683083.2010.03783.x

Ferreira, R. C., Gonçalves, T. X., Soares, A. R. D. S., Carvalho, L. R. D. A., Campos, F. L., Ribeiro, M. T. D. F., ... \& Ferreira, E. F. E. (2018). Dependence on others for oral hygiene and its association with hand deformities and functional impairment in elders with a history of leprosy. Gerodontology. 35(3), 237-245. https://doi.org/10.1111/ger.12346

Girdhar, B. K. (2016). Chemoprophylaxis. In: Kumar B, Kar HK. Editors. IAL Textbook of Leprosy. New Delhi: Jaypee Brothers Medical Publishers Ltd. p. 490-495.

Gopa, P. K. (2016). Psychososial aspects in leprosy. In: Kumar B, Kar HK. IAL Textbook of Leprosy. New Delhi: Jaypee Brothers Medical Publishers Ltd.p. 541-545. 
Hasnain, R., Queijo, J., Laher, S., \& Sandahl, C. (2020). Islam, Leprosy, and Disability: How Religion, History, Art, and Storytelling Can Yield New Insight and Acceptance. Societies. 10(1), 6. https://doi.org/10.3390/soc10010006

Hogeweg, M. (2010). Leprosy and the eye teaching set. International Centre for Eye Health, London. p. 1-41.

Hutahaean, B. S. H., \& Sumampouw, N. E. (2018). Pelatihan Peningkatan Self-Esteem pada Mahasiswa Universitas Indonesia yang Mengalami Distres Psikologis. Jurnal Ilmiah Psikologi MIND SET, 9(02), 97-114.

Hutapea, C. D. A., \& Mashoedi, S. F. M. (2019). Hubungan antara Optimisme dan Distres Psikologis pada Emerging Adults Miskin di DKI Jakarta. Jurnal Ilmiah Psikologi MIND SET, 10(02), 87-103.

Islam, F. M. A. (2019). Psychological distress and its association with socio-demographic factors in a rural district in Bangladesh: A cross-sectional study. PloS one, 14(3), e0212765. https://doi.org/10.1371/journal.pone.0212765

Kaur, H., \& Van Brakel, W. (2002). Is beggary a chosen profession among people living in a 'leprosy colony'?. Leprosy review, 73(4), 334-345.

https://pubmed.ncbi.nlm.nih.gov/12549841/

Kaur, I., Chakrabarti, A., Dogra, S., Rai, R., \& Kumar, B. (2003). Nail Involvement in Leprosy: A Study of 300 Patients1. International Journal of Leprosy and Other Mycobacterial Diseases, 71(4), 320.

\section{https://www.proquest.com/docview/216030194?pq-}

origsite $=$ gscholar \&fromopenview $=$ true

Kementerian Kesehatan Republik Indonesia. (2012). Pedoman Nasional Program Pengendalian Penyakit Kusta. Jakarta: Kementerian Kesehatan RI.

Kementerian Kesehatan Republik Indonesia. (2017). Profil Kesehatan Indonesia Tahun 2016. in D Budijanto, Yudianto, B Hardhana \& TA Soenardi (Eds.) Kementerian Kesehatan RI, Jakarta. p. 166-169.

Kementerian Kesehatan Republik Indonesia. (2018). Hapuskan Stigma dan Diskriminasi terhadap Kusta. Jakarta: Kementerian Kesehatan RI.

Krishnamurthy, K. V., \& Rao, S. P. (1990). A study of leprosy affected beggars in Aska. Indian journal of leprosy, 62(1), 113-115. https://europepmc.org/article/med/2141623

Malik, A. N. J., \& Morris, R. W. (2011). The prevalence of ocular complications in leprosy patients seen in the United Kingdom over a period of 21 years. Eye, 25(6), 740-745. https://doi.org/10.1038/eye.2011.43 
Matos, F. Z., Andreza-Maria-Fábio Aranha, Á. H., Borges, F. L. M. P., Raslan, S. A., Hamida, F., Veiga, K., \& Porto, A. N. (2018). Can different stages of leprosy treatment influence the profile of oral health? Oral status in leprosy. Medicina oral, patologia oral y cirugia bucal, 23(4), e376. https://dx.doi.org/10.4317\%2Fmedoral.22220

Menaldi, S. L. S. W. (2019). The Quality of Life of Leprosy Patients in Dermatovenereology Polyclinic of Dr. Cipto Mangunkusumo Hospital Jakarta: Study on Social Stigma. eJournal Kedokteran Indonesia, 6(3), 159-165. https://doi.org/10.23886/ejki.6.10107

Mohammed, S. B., \& Sookoo, R. (2016). Nutrient film technique for commercial production. Agricultural Science Research Journal, 6(11), 269-274.

https://www.researchgate.net/publication/309866285_Nutrient_Film_Technique_for_Co mmercial_Production

Olson, R. J., Braga-Mele, R., Chen, S. H., Miller, K. M., Pineda, R., Tweeten, J. P., \& Musch, D. C. (2017). Cataract in the adult eye preferred practice pattern®. Ophthalmology, 124(2), P1-P119. https://doi.org/10.1016/j.ophtha.2016.09.027

Pallagatti, S., Sheikh, S., Kaur, A., Aggarwal, A., \& Singh, R. (2012). Oral cavity and leprosy. Indian Dermatology Online Journal, 3(2), 101.

https://dx.doi.org/10.4103\%2F2229-5178.96700

Patki, A. H., \& Baran, R. (1991, March). Significance of nail changes in leprosy: a clinical review of 357 cases. In Seminars in dermatology (Vol. 10, No. 1, pp. 77-81).

https://pubmed.ncbi.nlm.nih.gov/2018724/

Pescarini, J. M., Strina, A., Nery, J. S., Skalinski, L. M., Andrade, K. V. F. D., Penna, M. L. F., ... \& Penna, G. O. (2018). Socioeconomic risk markers of leprosy in high-burden countries: A systematic review and meta-analysis, PLoS neglected tropical diseases, 12(7), e0006622. https://doi.org/10.1371/journal.pntd.0006622

Rajan, P., Premkumar, R., Rajkumar, P, \& Richard, J. (2005). The impact of hand dominace and ulnar and median nerve impairment on strenght and basic daily activities. Journal of Hand Therapy, 18(1), 40-45. https://doi.org/10.1197/j.jht.2004.10.011

Ramos, J. M., Reyes, F., \& Belinchón, I. (2013). Nail changes in recent and old leprosy patients. EMJ Dermatol, 1, 44-52.

https://www.emjreviews.com/dermatology/article/nail-changes-in-recent-and-oldleprosy-patients/ 
Rao, P. S. S., Mozhi, N. M., \& Thomas, M. V. (2000). Leprosy affected beggars as a hidden source for transmission of leprosy. Indian Journal of Medical Research, 112, 52. https://www.proquest.com/docview/195984171?pq-

origsite $=$ gscholar $\&$ fromopenview $=$ true

Reis, B. M., Castro, S. S. D., \& Fernandes, L. F. R. M. (2017). Limitation of activity and restriction of social participation in relation to age range, gender, and education in people with leprosy. Anais brasileiros de dermatologia, 92, 335-339.

https://doi.org/10.1590/abd1806-4841.20175216

Romero, I. B., Rincón, J. R., \& Rabell, F. R. (2012). Nail involvement in leprosy. Actas Dermo-Sifiliográficas (English Edition), 103(4), 276-284.

https://doi.org/10.1016/j.adeng1.2012.05.006

Scharlach, A. E., Kellam, R., Ong, N., Baskin, A., Goldstein, C., \& Fox, P. J. (2006). Cultural attitudes and caregiver service use: Lessons from focus groups with racially and ethnically diverse family caregivers. Journal of Gerontological Social Work, 47(12), 133-156. https://doi.org/10.1300/J083v47n01_09

Turnip, S. S., \& Hauff, E. (2007). Household roles, poverty and psychological distress in internally displaced persons affected by violent conflicts in Indonesia. Social Psychiatry and Psychiatric Epidemiology, 42(12), 997-1004. http://dx.doi.org/10.1007\%2Fs00127007-0255-3

van Brakel, W. H., Peters, R. M. H., Pereira, Z. B. S. (2018). Stigma Related to Leprosy-A Scientific View Part 1 Section 4 Chapter 4.5. International Textbook of Leprosy. https://m3u9w4p9.stackpathcdn.com/sites/default/files/ITL_4_5\%20FINAL.pdf

World Health Organization (WHO). (2016). Global Leprosy Strategy 2016-2020. World Health Organization.

World Health Organization (WHO). (2018). Blindness and vision impairment. World Health Organization.

Zhang, M., Zhang, J., Zhang, F., Zhang, L., \& Feng, D. (2018). Prevalence of psychological distress and the effects of resilience and perceived social support among Chinese college students: Does gender make a difference?. Psychiatry Research, 267, 409-413. https://doi.org/10.1016/j.psychres.2018.06.038 